\title{
Searching For a Voice \\ A Study of Alice Walker's The Color Purple
}

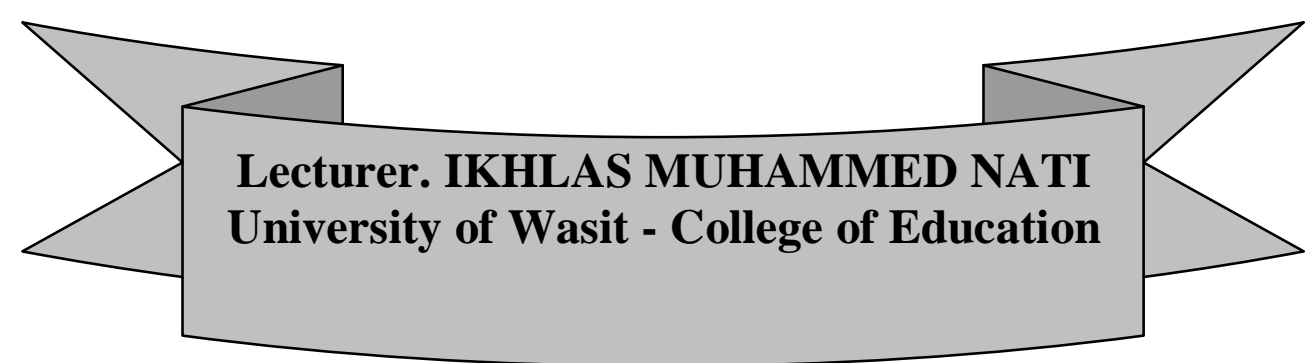

\section{Abstract:}

This paper focuses on the experiences of black African American women who have survived sexual violence and physical oppression in the age of slavery ( the nineteenth century) . Black women seek to find their freedom through expressing their voices. Thus they fight bravely to express themselves "their voices". And they try to understand how to be women, American, Black, and a variety of other things at once while remaining true to their true selves. Through the inspection of and encounter with these continuously warring elements, the AfricanAmerican race has defined and redefined the standards of being Black. Many black American women have persistent over the years to work towards abolition the unfairness of race and gender among other systems of oppression that they have experienced at home, at work, in their communities and within the overriding culture as a whole .

الملخص:

يركز هذا البحث تجارب النساء الأميركيات من أصول افريقية سوداء الأين نجوا من العنف

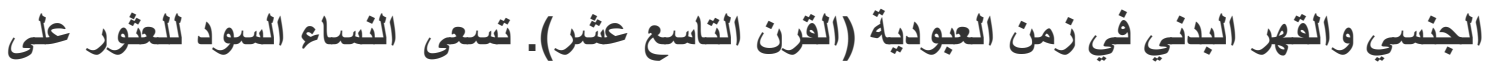

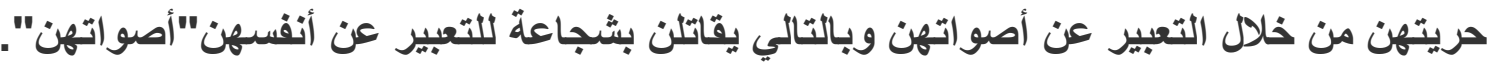
وأنهن يحاولن أن يثبتن ذاتهن كأمرأة، أمريكية، سوداء، ومجموعة متنوعة من الأشياء الأخرى

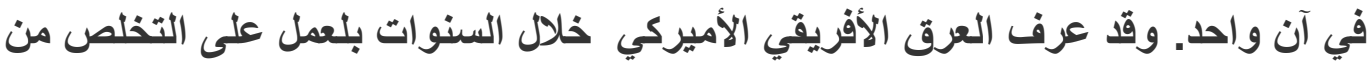

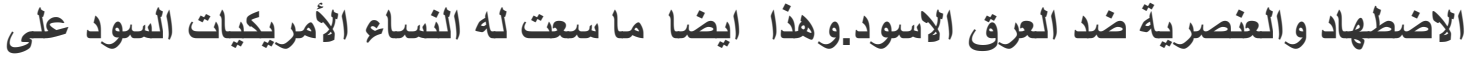

مدى السنوات العمل من أجل إلغاء الاضطهاد ضد العرق والجنس بين النظم الأخرى من القمع الأي تعرضوا لها في المنزل، في العمل، في مجتمعاتهن. 
Roderick Ferguson points out that most black women of the time plowed, planted, and hoed, did as much work as a men, endured the cruel chastisement meted out by slaveholders and their overseers, besides doing their natural role as mothers. But black women were not totally and always subservient to men. They wanted to be treated with the same respect as men, and they wanted equal opportunities in education, employment, self-determination on issues such as contraception, and abortion, enhanced public conveniences for child care, contraction of legal sanctions against aggression against women whether in the public or the private fields, and an end to the unfairness on grounds of sexuality, race, religion, and ethnicity. This means that women who are qualified for bureau must be given the same opportunities as men to become pastors and to serve in such leadership positions as deacons, stewards, trustees, etc. ${ }^{1}$

Over the course of history, misuse of the American black community has been deeply rooted into its soul. Goings J. Kenneth says: "Not only have they been made to suffer the unfairness inflicted upon them by white American men, they have also been made to suffer the vices of intraracism" ${ }^{2}$.Kenneth argues that the danger of racism from other cultures has always been a threat to the existence of America's black community. It is for this reason that the individual black communities joined together to form a stronger society .Intraracism became a problem among the black community of America. Black men were not better than their oppressors. They abused and belittled their black women .That is to say they used to silenced the black women . Besides, these women were denied access to white establishments, and they provided services for their own communities ${ }^{3}$.

At the end of the nineteenth century many African- American families had fallen into poverty. As Kenneth stated it became necessary for women and children to work. Women had to become full- time wage -earners for their families to get ahead economically. Racial prejudice 
kept them locked into such jobs as maids, laundresses and cooks ${ }^{4}$. These traditional female jobs allowed women to make only a small pay. Women were generally exploited by men, by whites, and by the patriarchal systems which control most countries, their governments, and their socioeconomics .Actually, these women lost their right to speak about their suffering, simply because they are silenced by the black men and their community. Moreover, Black women experienced a unique threat and menace in slavery - that of sexual assault. They were placed on the auction block, nude naked, and examined to establish their reproductive competence. Once they were sold, enslaved women often were coerced, bribed, induced, seduced, ordered, and of course, assertively imposed to have sexual relations with their slaveholders and overseers. Some slaveholders paired healthy slaves, a practice Peggy Pasco in his Race and Gender in the20th Century calls "slave breeding," for hard work. Black women's children could be sold to other slaveholders, which divided families and created indescribable sorrow. In other words, white men openly and systematically raped black women during slavery often doing so in order to breed black slave children to be sold for succumb away from their mothers and families. These abuses continued long after slavery was ended. Women's sexual services were part of their labor. White men also used the rape of black women as a technique of spreading arbitrary horror in the newly freed black communities of the South, and as a revenge against unchained black people who attempted to affirm their rights. ${ }^{6}$

During the twentieth century, job opportunities for African American women remained very limited beyond domestic jobs. They were engaged primarily as servants and familial workers. Desperate to support their families, they were coerced into providing sexual favors to their employers. Poor women who were unable to afford the psychotherapy charge, or to take time off from work, or even pay for transportation to counseling appointments were forced to engage in unwanted sex because a male partner had threatened or actually used 
force to obtain sexual access. If a black women wanted to continue in her job, then she must give her body to her master. She had no authorized right to talk or refuse. ${ }^{7}$

Jacqueline Jones asserts that slave children were estimated to work as soon as they were able to. Class for white men was indomitable by the sturdy fabrication of slaves and those who owned more slaves could dictate those who didn't. The forced exploitation of African-American women by white men was totally acceptable and authoritative as a means by which white men gained power and social status.As for white women, they became an important symbol of the supremacy of southern white aristocracy both during and after slavery. High standards were developed for their conduct and protection. They were strongly protected by law. Black men could never come close a white woman. Law repeatedly assigned the death consequence to black men accused and convicted of raping white women, but rarely to assailants white or black -who raped black women. ${ }^{8}$

All throughout history, Jones argues, black women have been fighting against the laws, structures, and so-called "norms" of society that constrained them based on sex or gender. Sexual violence has been a tool of suppression for centuries. Only within the $20^{\text {th }}$ century have rape, sexual enslavement and sexual violence been highlighted as elements of genocide or crimes against humanity and prosecuted as such. Rape has successfully been prosecuted as a form of persecute, a means of persecution and enslavement'. This might explain why describing the double challenges race and gender becomes a mission for black women writers. The task is critical because, even in today's inclusionary nonfiction environment, the full story of racism and sexism is rarely told or is offered in a sanitary version. Racism and sexism are omnipresent, repressive, and dehumanizing. In most of the works of fiction, black women authors bear witness of their fight for liberation. The evidence they give is egalitarian; it will not be found in any history books because it shames those essentials of society who seek to 
marginalize evidence of social unfairness. In her narrative, The Color Purple published in 1982 , Alice Walker (1944 - ), who was recognized as one of the leading voices among black American women writers, portrayed the struggle of black people throughout history, and her work was praised for its insightful and spellbinding portraits of black life, in particular the experiences of black women .She tackled the traditional subjects of feminism and racism against blacks. Walker's novel focuses on male brutality against women across cultural lines. The Color Purple is an excellent account of the life of poor black women who suffered not only social ostracism due to gender and skin color but also women who suffer greatly at the hands of black men. This is true in terms of infidelity, physical and verbal abuse, and sexual abuse. Alice Walker wrote perceptively about the precise inflections of racial and gender difference in her experience of being both black and female. She reflected the conditions of those black people and the values they represented within the larger context of American society. The subject matter is the utilization of black women by their men, and in exploring this theme, Walker herself suffered a lot at the hands of those men she knew in her life ;therefore, the novel is considered a true cry out for assist and for a different life. She wrote that "Slavery is terrible for men; but it is far more terrible for women." 10

Walker's novel recognizes that women, especially black women, will be able to achieve more justice if they work together, transcending national and cultural borders. It ignites controversy especially from African- American men who claimed Walker's novel was inventive male-bashing. Walker admired the struggle of black women throughout history to sustain an essential spirituality and ingenuity in their lives, and their achievements serve as an encouragement to others. Her women characters show strength, endurance, and resourcefulness in confronting - and overcoming - oppression and all types of abuses physical, verbal and sexual abuse in their lives. Walker said in one of her novels "Black women are called, in the folklore that so aptly

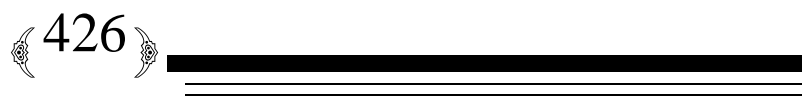


identifies one's status in society, the 'mule of the world,' because we have been handed the burdens that everyone else - everyone else refused to carry." 11 Paul Steven in his African American women noted that:

The true empathy Alice Walker has for the oppressed woman comes through in all her writings.... Raising an ax, crying out in childbirth or abortion, surrendering to a man who is oblivious to her real name - these are the kinds of images which most often appear in Ms. Walker's own writing. ${ }^{12}$

Steven adds that the strength of such images is that Walker sheds lights on "the intimate reaches of the inner lives of her characters; the landscape of her stories is the spiritual realm where the soul yearns for what it does not have." 13

Kenneth Kevin in Race and Violence Against Black Women called Walker "a provocative writer who writes about blacks in particular, but all humanity in general."14 While Spenser Kimberly in the Third Wave Black Feminism wrote that although Walker's "original interests centered on black women, and especially on the ways they were abused or underrated ... now those interests encompass all creation." 15

The Color Purpl is often used as an example of a woman's novel. For Walker, womanly writing is that which focuses on AfricanAmerican women in twentieth-century America. This tradition of novels tends to deal with the oppression of African-American women. In these novels, we often meet women who fight against all kinds of abuses for their survival and for the survival of their families. In their disorganized and dislocated communities, these women are often mothers who seek to protect and bring together their families for the sake of future generations. Walker's The Color Purple, tells the story of Celie, the young black girl living in Georgia who has never known any life but one with male violence in it. That violence has been shaped in a large part by the financial and social realities of being black in America, but from the point of view of one black girl, all that matters is that she is on the 
receiving end of the blows . Celie, is subjected to a considerable abuse because she is a female. In the country where Celie lives women are inferior to men. When women try to assert themselves they get beaten: "domestic violence is often triggered by a woman failing to meet a man's expectations about 'his' woman's responsibility to provide sexual and caring services"16. But through the strong women role models in her life, Celie learning her own self-worth, is able to leave an abusive relationship, and find interior peace . Celie writes letters to God in which she talks about her life--her role as daughter, wife, sister, and mother. She has been trodden down and sexually abused since childhood. She has been depressed of basic human rights such as freedom, will of self-determination, and ownership of her own body . In order to find herself and gain independence, Celie must deal with all manners of abuse, including misogyny, racism and poverty. When she is a young girl of 14, she is sexually assaulted by Alfonso, the man she thinks her father. She has two children from him but he takes them both and sells them for money. She does not find out until late in the novel that Alfonso was not her real father, but someone who married her mother after the death of her father. When her mother dies, this man known as "Pa" forces her to marry a man she refers to as "Mr. ---. Verbal and physical abuse is a constant in Celie's life. The man she married makes her raise his two children from another marriage, despises her, and physically and verbally abuses her. He insults her in every possible way .He calls her skinny, stupid, ugly,and worthless. Celie's mother has several children to look after, and when she falls ill, Celie takes over the hard work. Because of Alfonso, Celie begins to protest to God by writing series of letters that include her abuses and the aggression done to her by the idle provoker, Alfonso in order to express herself. She is afraid that the terrible news of her mugging and the exploitation she received from the man who is supposed to be her father might kill her mother, but after her mother's death, she continues to write. Celie's family life is very distressing. Celie's mother dies as early as Celie's second diary entry. Alfonso marries a girl the

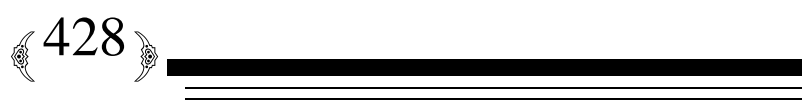


same age as Celie. He even becomes interested in pursuing his younger daughter, Nettie, Celie's sister. Thus crating a family of fear. It is an understatement to say that the man in the family cannot be trusted. Celie has to challenge with many social issues, including" mysogyny, racism, poverty and her lesbianism".${ }^{17}$ Celie is completely at the mercy first of her cruel "Pa", who rapes her, and then at the mercy of Mr... her husband to whom Alfonso has married her off after the death of her mother. He beats her and abuses her and forces sex on her. She does not like sex and sees it as something that is done to her, not something she takes part in. She is further dominated when her husband brings his sick mistress to the house for her to look after. She is totally ineffective. $^{18}$

In the novel we see such changes happening. Celie is able to set up her own business. She works in the same house where her father lived and worked. Thirty years earlier, her father's life was cut short by white rivals fervent to keep him down. In this new generation, Celie will continue to prosper. In other words, the abused black girl who addresses her letters to "Dear God," has at last made up her own life regardless of her a male-dominated and racially unfair society. In the course of her story, Celie meets a series of other Black women who shape her life . As she gets stronger,she succeeds in overcoming the neglect she experienced with the help of those women who surround and encourage her to affirm herself . The most significant women in Celie's life are sister Nettie, her daughter-in-law, Sofia and the singer Shug Avery. These are the women who lead Celie out of her shell and help her turn from and shy, solitary woman to someone who is free to speak her mind and lead her own independent life. Through the positive and encouraging relations with those women Celie becomes more human and more confident of herself. She learns that the survival and liberation is through the strength and wisdom of others. ${ }^{19}$

Celie is motivated by her sister's freewill, determination and firmness in Africa among foreign people. She saw the force that a

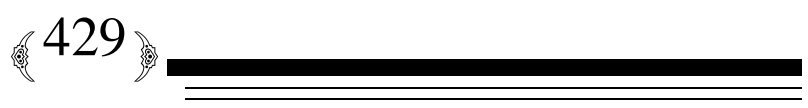


woman could have on others and felt empowered to feat over the malice she experience. Nettie is someone that Celie tries to protect from the physical and sexual abuse of their father. It is also Nettie whom Celie looks to for education when her father pulls her out of school. Nettie was the one who always supports and loves Celie. When Nettie runs away, Mr. hides the letters sent to Celie to revenge himself on Nettie because she refuses to have any sexual relationship with him . He cuts off the sisters' communication, which left them disconsolate. The real turning point for Celie is when she learns that her husband has been hiding all of her mail which included hundreds of letters from her loving sister Nettie

Celie had been getting mail from her sister Nettie for years, but Mr. kept it all from Celie, so she would not even know Nettie was still alive. Mr. The state makes her emotional strength raise; it also increases her hatred for her husband. She leaves him and moves in with Shug and starts her own business. With Shug's help she has not only learned to live, she has learned to love as well. Sophia is a strong woman who at first frightened Celie but after getting to know each other they become friends and they support each other in the course of the misuse they each suffer through. Sophia's size and attitude came as a shock to Celie when Mr. 's son Harpo brings her to the house for his father to meet. She does not let Harpo's father talk down to her, and talking back was something Celie thought she could never bring herself to do. "I say it cause I'm a fool, I say. I say it cause I'm jealous of you. I say it cause you do what I can't. What that? she say. Fight. I say." 20 When Sophia would not pay attention to Harpo's request, after Celie's suggestion, he tries to hit her as his father did to Celie but Sophia fights back. Sophia reveals that she pitied Celie and tells her she should struggle back too. It is after that conversation that Celie and Sophia support each other and become friends. After a time, when Sophia is seen by the mayor and his wife in town, they comment on how charming their children looked. The mayor's wife asks Sophia if she would like to work for her as her maid, which upsets Sophia. When Sophia refuses,

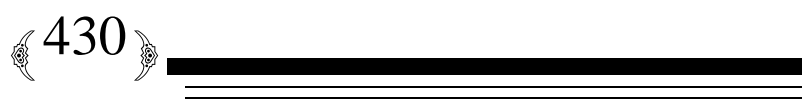


the mayor slaps her and in return she knocks him down. As a result, Sophia is beaten to near death and put in prison. Through all this, Sophia stays as strong as she can and still does not let anyone tell her what to do. When Sophia is let out of prison she is sent to work for the mayor's wife as a punishment. She is not allowed to see her family or any men but she still does not forfeit. Celie still goes to visit her through this experience and their friendship stays strong. Sophia and Nettie are family to Celie . Shug Avery is someone Celie admired from a young age. Shug's enthusiasm and charm with people are qualities Celie never dreamed of having herself until Shug walks into her life and Celie does more with her life by actually overcoming the neglect and becomes someone else . Shug comes into Celie's life as her husband's mistress who was very ill but not lacking in character. She treats Celie with disrespect at first, but after living with her for some time and being nursed back to health by her, Shug gains a respect for her. She teaches Celie how to speak for herself and to defend herself against Mr.

Shug is the one who helps Celie break out by taking her on her excursion where Celie learns how to expertly sew pants. This is another major step towards self-determination because Celie is no longer monetarily dependent on anyone but herself because she creates a successful business by making pants. Upon her return, she inherits her father's home .In that way she is completely separated from the men who held control over her. She can now receive her sister's letters and make her own money. The people who love her surround her and her personality develops unhindered by abuse. Shug helped Celie to realize she was not only discriminated against by racism in society, but that she was also a victim of intra-racism. Celie began to see people for what they really were. She saw the pig-headed males who stole away the very essence of her womanhood. ${ }^{21}$

After Celie's new liberty, her relationships flourish and she and Mr. __ develop a new relationship as friends, where there is no vulgarity but only respect. Celie is able to build up her individualism through experience of mistreatment and rise above it because of the aid 
from three dominant women in her life, Nettie, Sophia and Shug. All of these women play roles of importance throughout different stages of Celie's life and while Celie could have survived on her own, these women taught Celie not only how to survive, but how to really live. Celie transformed from a self-loathing injured little girl into a selfmotivated, strong-minded woman. Her courage to break away from the social standard astounds audiences to this day. ${ }^{22}$

Alice Walker wrote this novel with hope for female endurance and with a sense of numinous wonder. The protagonist of this story lives a nasty existence of racism and sexism, but she maintains her own dignity. With the help of Shug Avery, she is given a second chance for success, for life, and for love. Rape, incest, sex, forced labor, and other themes are referred to in this novel. Each one of these aspects had a enduring intuition upon the ideals and notions of the time. Walker's writings helped to break the racial barricade that existed in some people's minds. One way that the barrier was destroyed was through Walker's illustration of an imperfect black person. Now that a black person is writing about other blacks that are foretaking in acts that are, in their eyes, decadent and distort, the subject is brought into a new light. ${ }^{23}$

Celie finds a way to break away from the silence she has had to undergo and finds her voice, her strength and her freedom. Celie journeys from a place of full silence and with the help of the women in her life and the desertion of gender-roles in the community she is able to stand up and assert her voice and her life.

\section{Notes:}

${ }^{1}$ Roderick Ferguson, Alice Walker's Major Works (Bloomington : Indiana University Press, 1987),p.323 ${ }^{2}$ Goings J. Kenneth, Alice Walker 's The Color Purple(Harvard University Press, America,1989),p.87

${ }^{3}$ Ibid,p.88

${ }^{4}$ Ibid,p.78 
${ }^{5}$ Peggy Pasco, Race and Gender in the20th Century(Bloomington :

Indiana University Press, 1994),p.76

${ }^{6}$ Ibid,p.56

${ }^{7}$ Charles L. Bloom, Walker's Women(New York: Norton and Company, 1988),p.35

${ }^{8}$ Jacqueline Jones, Black Women in America and Age of Slavery (New York: $\quad$ Oxford University Press, 1991),p.127

${ }^{9}$ Ibid,p.122

${ }^{10}$ bid,p.143

${ }^{11}$ Paul Steven, African American Women (Harvard University Press, America.1987),p.76

${ }^{12}$ Ibid.,p.54

${ }^{13}$ Ibid., p.43

${ }^{14}$ Kenneth Kevin, Race and Violence Against Black Women (Md.: Black Classic Press, 1994),p. 30

${ }^{15}$ Spenser Kimberly, Third Wave Black Feminism (Bloomington :

Indiana University Press, 1994),p.23

${ }^{15}$ Ibid,p.26

${ }^{16}$ Ibid,p.39

${ }^{17}$ Patricia Hill Collins, A Study of the Works of African American Writers (New York: Vintage Books, 1995),p.35

${ }^{18}$ Daniel Hoffman, Voices from the South(Chapel Hill : University of North Carolina ${ }^{4}$ Ibid,p Press, 1989),p. 65

${ }^{19}$ Barbara Christian, "Alice Walker," in Black Women Writers( New York: $\quad$ Oxford University Press, 1991),p.98

${ }^{20}$ Alice Walker, The Color Purple ,1983

${ }^{21}$ Henry Gates Louis, Alice Walker: Critical Perspectives: Past and Present(New York: Oxford University Press, 1993),p.45 
${ }^{22}$ Ibid,p.32

${ }^{23}$ Ibid,p.56

Bibliography

Alice Walker, The Color Purple 1983 Weidenfeld Nicolson,2011.Ebook (www.ivsl.org.com)

Ferguson, Roderick. Alice Walker's Major Works. Bloomington :

Indiana University Press, 1987.

Kenneth, Goings J. Alice Walker 's The Color Purple. Harvard

University Press, America,1989.

Pasco, Peggy .Race and Gender in the20th Century. Bloomington :

Indiana University Press, 1994.

Bloom, Charles L. Walker's Women .New York : Norton and Company, 1988.

Jones, Jacqueline. Black Women in America and Age of Slavery .New York: Oxford University Press, 1991.

Steven ,Paul. African American women .Harvard University Press, America.1987

Kevin, Kenneth .Race and Violence Against Black Women , Md.: Black Classic Press, 1994.

Kimberly ,Spenser. Third Wave Black Feminism .Bloomington : Indiana University Press, 1994.

Collins, Patricia Hill. A Study of the Works of African American Writers .New York: Vintage Books, 1995.

Hoffman ,Daniel. Voices from the South. Chapel Hill : University of North Carolina Press, 1989.

Christian, Barbara. "Alice Walker," in Black Women Writers. New York: Oxford University Press, 1991.(www.isvl.org.com).

Louis, Henry Gates, Alice Walker: Critical Perspectives Past and Present, New York:Oxford University Press, 1993.(www.isvl.org.com). 